\title{
Impact of temperature on larval development and evolution of physiological indices in Crassostrea gigas
}

\author{
R. Ben Kheder ${ }^{a}$, J. Moal $^{a}$ and R. Robert ${ }^{\mathrm{a},{ }^{*}}$ \\ a Ifremer, Laboratoire de Physiologie des Invertébrés Marins, Station Expérimentale d'Argenton, \\ Presqu'île du Vivier, 29840 Landunvez, et Centre de Brest, BP 70, 29280 Plouzané, France \\ *: Corresponding author : R. Robert, Tel.: + 332988951 05; fax: + 332988957 77, email address : \\ rene.robert@ifremer.fr
}

\begin{abstract}
:
The effect of four temperatures, ranging between $17^{\circ} \mathrm{C}$ and $32{ }^{\circ} \mathrm{C}$, was studied on development and lipid reserve management of Crassostrea gigas larvae. No effect of temperature was found on larval mortality, as high survival (>90\%) was recorded before competence at all temperatures studied. Temperature did, nonetheless, have a strong effect on growth and settlement success. At low temperature $\left(17^{\circ} \mathrm{C}\right)$, larvae competent to metamorphose were only observed from day 23 and only a low percentage finally achieved metamorphosis (12\%). The opposite was seen at temperatures $\geq 27^{\circ} \mathrm{C}$ : larval competence appeared at day 18 and led to high rates of metamorphosis (60-90\%). This difference at settlement seemed to be linked to larval growth, which showed rates of $7 \mu \mathrm{m} \mathrm{d}^{-1}$ at $17^{\circ} \mathrm{C}$ vs. $10.5 \mu \mathrm{m} \mathrm{d}^{-1}$ at $32^{\circ} \mathrm{C}$. In addition, a higher accumulation of lipid reserves at low temperature was revealed by both biochemical (TAG/ST) and colorimetric (OLI) methods. In fact, the lower the temperature, the higher the mean TAG/ST levels recorded $\left(6-9\right.$ at $17^{\circ} \mathrm{C}$ vs. $2-4$ at $\left.32{ }^{\circ} \mathrm{C}\right)$. In the same way, larvae reared at $17{ }^{\circ} \mathrm{C}$ had a percentage lipid surface coverage between 19 and $29 \%$ (at sizes between 80 and $230 \mu \mathrm{m}$ ), while lipids covered only 5 to $16 \%$ of the surface of larvae reared at $32{ }^{\circ} \mathrm{C}$ (at size $<250 \mu \mathrm{m}$ ). Neither of these physiological indices can, however, provide a relevant indication of the larval performance induced by different rearing temperatures.
\end{abstract}

Keywords: Crassostrea gigas; Larvae; Growth; Metamorphosis; Temperature; Lipids; Physiological indices 


\section{Introduction}

Since the introduction of Crassostrea gigas to French coasts in the 1970s, this species has been grown in all the main oyster farming basins, where it now represents $99 \%$ of French oyster production (Buestel et al., 2009). Until recently, the industry relied on supplies of wildcaught spat collected in the nursery basins of Marennes-Oléron and Arcachon (AGRESTE, 2005). Due to high interannual fluctuations in settlement and growing interest in triploid seed, however, an increased demand for hatchery-produced oyster spat has developed. Although greater technical control is required over all stages in the hatchery (Robert and Gérard, 1999), it is the larval and early postlarval stages that are the most sensitive in the mollusc life cycle (Helm et al., 2004) and no viable predictive tool yet exists. The usefulness of three physiological indices, larval condition index (OM/DW), structural biochemical index (TAG/ST) and overall lipid index (OLI) have been investigated in previous studies, which looked at the evolution of these indices in larvae fed diets of differing quality and quantity (Ben Kheder et al., $2010 \mathrm{a}$ ), and during periods of temporary starvation (Ben Kheder et al., $2010 \mathrm{~b}$ ).

OM/DW appears to be the least relevant of these three indices (Ben Kheder et al. $2010 \mathrm{a}$ ). We therefore concentrated the present study on the other two, TAG/ST and OLI, which are lipid-based. Indeed lipids are known to be the main energetic reserves in many bivalves (Knauer and Southgate,1999). Our objective was to look at the effect of four temperatures, varying from 17 to $32{ }^{\circ} \mathrm{C}$ on larval rearing performances of $C$. gigas and the evolution that occurs in these chosen lipidic indices over larval development. Such temperature scale was chosen because it allowed Pacific oyster larval development with high survival (Rico-Villa et al., 2008). Temperature is the most important factor influencing mollusc rearing, after nutrition, especially during the pelagic phase (Helm et al., 2004). It is generally accepted that larval survival is high at low temperature, but that growth is stimulated as temperature increases (Doroudi et al., 1999). Temperature also acts on the metabolism by overall acceleration of all metabolic functions, like respiration and ingestion (Rico-Villa et al., 2009), and is therefore a major factor regulating energetic requirements of individuals. Rearing temperature has also been shown to interact with food-related factors to affect mechanisms involved in the laying down of lipid deposits. In the trout in particular, the transport of lipids is accelerated at low temperature but neosynthesis capacity is lessened (Corraze et al., 1999).

\section{Materials and methods}

The experiments were conducted using genitors conditioned according to methods described in Ben Kheder et al. (2010 a). Following a controlled fertilisation using gametes from three males and six females, groups of the resulting larvae were reared at $17,22,27$ and $32{ }^{\circ} \mathrm{C}$ at a density of 30 larvae $\mathrm{ml}^{-1}$ in duplicate $150 \mathrm{~L}$ cylindro-conical tanks in a flow through rearing system. These temperatures were maintained constant throughout the rearing period using thermo-regulated automatic valves. The larvae were fed continuously with Isochrysis affinis galbana (T-ISO: strain CCAP 927/14) and Chaetoceros calcitrans forma pumilum (strain CCAP 1010/05) at a 1:1 cell biovolume. In a static rearing system the quantity of food supplied during larval and settlement stages depends on uptake of microalgae by larvae that showed a constant consumption increase during week 2 (after fertilisation) and a sharp decrease during metamorphosis (Rico-Villa et al., 2006). In a continuous rearing system, whatever biomass and renewal seawater flow, phytoplankton should be maintained at a constant level to improve growth performances (Rico-Villa et al., 2008). A phytoplankton level of $1000 \mathrm{um}^{3} \mu^{-1}$ (17 cells $\mu \mathrm{l}^{-1}$ ) was accordingly continuously maintained for a seawater flow of $201 \mathrm{~h}^{-1}$ (seawater renewal rate $: 13 \% \mathrm{~h}^{-1}$ ). Once a week the tanks were emptied so that the rearing structures could be cleaned and larval survival estimated. Intermediate samples were taken from the rearing tanks every 2-4 days for the study of growth. At the end of larval rearing period, from day 18 , when $\geq 30 \%$ of the population was competent (larvae with active foot and eyes) plastic disks (15 cm diameter) were placed in larval rearing tanks and used as 
collectors. Postlarvae developed a new shell (dissoconch) and mainly settled on collectors. After 5 days, metamorphosis was evaluated by counting the number of remaining larvae and subtracting them from the total number of larvae initially present. An estimation of spat attached to collectors and tank walls was performed to confirm results.

Throughout whole larval life samples for physiological indices measurements were regularly taken. Such analysis techniques have been previously detailed (Ben Kheder et al., 2010a) so only a brief outline will be given here. Overall lipid index (OLI) was calculated on 50 individuals per tank, every 4 days, by coloration of neutral lipids with Nile Red, followed by their quantification using image analysis to calculate lipid surface relative to total larval surface. The second index TAG/ST was measured, every 2 days, by means of analysis of lipids after preservation of samples of larvae (50 000 to 200000 according to their development stage) in Folch's liquid, and neutral lipid classes were analysed in HPTLC (high performance thin layer chromatography) using a CAMAG system.

Larval performances were analysed by one-way analysis of variance followed by Fisher's Least Significant Difference pairwise comparison $(P<0.05)$; where necessary data were arcsine transformed to achieve homogeneity of variance and normality using Statview 5, SAS Software. Data are summarized as mean \pm standard deviation of the mean. After logarithmic transformation of lipidic indices slope-fitting tests were made on the data, according to temperature, using $\mathrm{R}$ software. The significance of the slopes was tested with $\mathrm{t}$ tests.

\section{Results}

\subsection{Larval performances}

Survival at the end of larval development was found to be similarly high at all rearing temperatures (> $90 \%$ : Table 1). Other parameters were more variable with temperature because the higher the temperature, the shorter the duration of the larval phase. At high temperatures therefore, $\left(27\right.$ and $\left.32{ }^{\circ} \mathrm{C}\right), 33$ to $43 \%$ of larvae were competent at 18 days, successfully becoming post-larvae in 60 to $90 \%$ of cases (Table 1). Inversely, at $17{ }^{\circ} \mathrm{C}$, the percentage of competent larvae was only $17 \%$ at day 23 and only $12 \%$ became post-larvae.

\subsection{Structural biochemical index: TAG/ST}

The kinetics of triacylglycerol accumulation followed an exponential pattern in relation to larval size (Fig 1a), with this form of curve fitting the data satisfactorily for all rearing temperatures $\left(0.83>R^{2}>0.93\right)$. At an equivalent size, the increase in triacylglycerols in the larvae was greatest at $17{ }^{\circ} \mathrm{C}$. At day 23, therefore, a mean value of $120 \mathrm{ng}$ was found at 17 ${ }^{\circ} \mathrm{C}$ in individuals measuring $230 \mu \mathrm{m}$, while at 27 and $32{ }^{\circ} \mathrm{C}$, contents were 33 and $20 \mathrm{ng}$, respectively, for larvae of a similar size (Fig. 1a). Sterols also accumulated according to an exponential curve (Fig. 1b), which fitted the relationship at all rearing temperatures $\left(0.98>R^{2}\right.$ $>0.95$ ). Above $150 \mu \mathrm{m}$, accumulation of sterols by larvae was more marked at $17{ }^{\circ} \mathrm{C}$, but contents recorded at higher temperatures (between 22 and $32{ }^{\circ} \mathrm{C}$ ) only showed slight differences at equivalent size (Fig. 1b). In contrast, no relation was found between the TAG/ST ratio and larval size (Fig. $2 a)$ at any of the temperatures studied $\left(R^{2}<0.19\right)$. This lack of correlation was confirmed by a test, showing that no slope was statistically different from zero. It is nevertheless interesting to point out an increasing gradient of mean TAG/ST values with decreasing temperature: at $32{ }^{\circ} \mathrm{C}$ TAG/ST values were between 1.5 and 5 , contrasting with values of 6 to 12 at $17^{\circ} \mathrm{C}$. 


\subsection{Overall lipid index}

As with TAG/ST, no relationship was found between OLI and larval size at any of the rearing temperatures (Fig. 2b); the correlation coefficients were between 0.25 and 0.51 , apart from at $27{ }^{\circ} \mathrm{C}$ where $\mathrm{R}^{2}=0.79$. This overall absence of correlation was confirmed by t test. Here again the highest values, except for larvae at hatching, were recorded in veligers reared at $17{ }^{\circ} \mathrm{C}\left(19-29 \%\right.$, compared with $5-16 \%$ at $\left.32{ }^{\circ} \mathrm{C}\right)$.

\section{Discussion}

No effect of temperature on larval mortality until competence was found in our study, as survival at the end of larval development was always above $90 \%$ at all temperatures tested (between 17 and $32{ }^{\circ} \mathrm{C}$ ). Conversely, the influence of temperature on larval growth is clearly demonstrated and agrees with the work of His et al. (1989) conducted in a static flow system over a week. In the present study, the optimal performances recorded at $32{ }^{\circ} \mathrm{C}$ could be explained by an overall stimulation of the metabolism, as previously demonstrated in larvae of C. gigas (Rico-Villa et al., 2009). Furthermore, temperature can modify the efficacy of digestion as suggested in the green mussel (Nair and Appukuttan, 2003), or affect the efficiency of certain enzymes involved in neosynthesis or lipid transport in trout (Corraze et al., 1999).

Indices from the two methodological approaches used in this study, biochemical (TAG/ST) and colorimetric (OLI), showed no relationship with larval size at any rearing temperature. However, lipid storage appeared to be more pronounced at low temperature. Larval metabolism is slower at $17{ }^{\circ} \mathrm{C}$ and a preferential accumulation of TAG was noted, together with small amounts of ST, leading to higher values of TAG/ST than those recorded at higher temperatures. In the same way, we demonstrated that the lipidic surface is greater at low temperature. These results agree with those of Farias et al. (2003), who noted an increase in cholesterol and steryl esters in Argopecten purpuratus at low temperature. Also, the decrease in rearing temperature from 22 to $16{ }^{\circ} \mathrm{C}$ in seabass increases the lipid content of muscle (Richard, 2006). According to the author, it appears that ß-oxidation is less activated at low temperature. In $C$. virginica, a slight accumulation of lipids in the digestive gland was reported in larvae reared at $25^{\circ} \mathrm{C}$ (compared with $30^{\circ} \mathrm{C}$ ) by Gallager et al. (1986), who noted that larvae became competent at $32{ }^{\circ} \mathrm{C}$ but did not metamorphose because they did not have enough lipid reserves. The data of the present study disagree with those found by these previous authors because, although reserves diminished with temperature, metamorphosis was high $(91 \%)$ at $32{ }^{\circ} \mathrm{C}$ with moderate lipid reserves (OLI $\left.\approx 15 \%\right)$. On the other hand, a poor rate of metamorphosis success $(12 \%)$ was found at $17^{\circ} \mathrm{C}$ in larvae with reserves almost twice as high $(27 \%)$. Similarly, temperature had positive effects on metamorphosis with high settlement related to high larval competency for temperatures $\geq 27^{\circ} \mathrm{C}$ and, in contrast low effects at temperatures $\leq 22^{\circ} \mathrm{C}$ with an important delay in competency achievement. This delay in competency and settlement can be explained by slower growth at 17 and $22{ }^{\circ} \mathrm{C}$, which was 7 and $8.7 \mu \mathrm{m} \mathrm{d}^{-1}$, respectively, compared with $10.6 \mu \mathrm{m} \mathrm{d}^{-1}$ for the temperatures $\geq 27^{\circ} \mathrm{C}$. Metamorphosis success is clearly related to temperature and not to lipids accumulation. Indeed neither of these physiological indices can, provide a relevant indication of the larval performance induced by different rearing temperatures.

Temperature also has a fundamental influence on membrane lipid metabolism. The study of variations in lipidic composition of membranes with temperature has led to the development of the theory of homeoviscous adaptation (Hulbert et al., 2007). Thus modification of membrane fluidity allows these ectothermic organisms to adapt to temperature changes. Membrane lipids are remodelled by changes in the composition of phospholipids, fatty acids and cholesterol content in relation to temperature acclimation (Hazel and Williams, 1990). Cholesterol is an essential component of animal membranes, with multiple effects on their physical properties, including membrane fluidity, thickness and permeability (Crockett, 1998). 
It was demonstrated that the quantity of sterols in bivalve molluscs increases as the temperature rises, and that this serves to stabilise the membranes and their associated enzymes (Pernet et al., 2006). Our results appear to suggest, in contrast, that homeoviscous adaptation by increase in sterols with temperature does not apply to the early stages of bivalve development. However, most studies on homeoviscous membrane adaptation to temperature describe regulation by the desaturation of fatty acids or the relative composition in terms of PC/PE (phosphatidylcholine / phosphatidylethanolamyne), aspects that the present study did not examine. Chromatographic doses of polar fatty acids and more detailed studies on the class of sterols in C. gigas larvae will allow us to validate these first results.

Finally, while these two parameters were particularly relevant for showing the quantitative and qualitative influence of nutritional factors (Ben Kheder et al., $2010 \mathrm{a}$ and b), they did not allow us to examine at the physiological aspects of rearing performance differences due to temperature.

\section{Acknowledgments}

This work could not have been completed without the technical support of the team at the Argenton Ifremer station: C. Mingant, I. Quéau, L. Lebrun and P. Le Souchu. The authors also wish to thank I. Bernard, PhD student, for his statistical assistance in slope regression analysis. Rym Ben Kheder is also grateful to the Tunisian ministry of higher education, scientific research and technology, the French embassy in Tunis and the Centre Régional des Fuvres Universitaires et Scolaires de Rennes, who contributed to the funding her doctoral visit to France.

\section{References}

AGRESTE, 2005. AGRESTE Pimeur, premier Recensement de la conchyliculture 2001, Agreste Cahiers $\mathrm{n}^{\circ} 1$, février 2005, $89 \mathrm{pp}$.

Ben Kheder, R., Quéré, C., Moal, J., Robert, R. 2010 a. Effect of nutrition on C. gigas larval development and the evolution of physiological indices. Part A: quantitative and qualitative diet effects. Aquaculture 305, 165-173.

Ben Kheder, R., Quéré, C., Moal, J., Robert, R. 2010 b. Effect of nutrition on C. gigas larval development and the evolution of physiological indices. Part B: Effects of temporary food deprivation. Aquaculture, accepted.

Buestel, D., Ropert, M., Prou, J., Goulletquer, P., 2009. History, status, and future of oyster culture in France. J Shellfish Res. 28(4), 813-820.

Corraze, G., Larroquet, L., Médale, F., 1999. Alimentation et dépôts lipidiques chez la truite arc-en-ciel, effet de la température d'élevage. INRA Prod. Anim., 12 (4), 249-256.

Crockett, E.L., 1998. Cholesterol function in plasma membranes from ectotherms: Membrane-specific roles in adaptation to temperature. American Zoologist 38, 291-304.

Douroudi, M.S., Southgate, P.S., Mayer, R.J., 1999. The combined effects of temperature and salinity on embryos and larvae of the black-lip pearl oyster, Pinctada margaritifera. Aqua. Res. 30, $271-277$.

Farias, A., Bell, J. G., Uriarte, I. \& Sargent, J. R., 2003. Polyunsaturated fatty acids in total lipid and phospholipids of chilean scallop Argopecten purpuratus (L.) larvae: effects of diet and temperature. Aquaculture 228 (1-4), 289-305.

Gallager, S.M., Mann, R., \& Sasaki, G.C., 1986. Lipid as an index of growth and viability in three species of bivalve larvae. Aquaculture 56(2), 81-103.

Hazel, J.R, Williams, E.E, 1990. The role of alterations in membrane lipid composition in enabling physiological adaptation of organisms to their physical environment. Prog. Lipid Res. 29, 167-227. 
Helm, M.M., Bourne, N., Lovatelli, A., 2004. Hatchery culture of bivalves. A practical manual. In: Lovatelli, A. (Ed.), FAO Fisheries Technical Paper 471. Food and Agriculture Organization of the United, Nations Publishing, Rome, Italy. 177 pp.

His, E., Robert, R., Dinet, A., 1989. Combined effects of temperature and salinity on fed and starved larvae of the Mediterranean mussel, Mytilus galloprovincialis and the Japanese oyster Crassostrea gigas. Mar. Biol., 100, 455-463.

Hulbert, A.J., Pamplona, R., Buffenstein R., Buttemer W. A., 2007. Life and death: Metabolic rate, membrane composition and life span of animals. Physiol., Rev., 87, 1175-1213.

Knauer, J., Southgate, P.C., 1999. A review of the nutritional requirements of bivalves and the development of alternative and artificial diets for bivalve aquaculture. Rev. Fish. Sci. 7, 241-280.

Nair, M., Appukuttan, K.K., 2003. Effect of temperature on the development, growth, survival and settlement of green mussel Perna viridis (Linnaeus, 1758). Aqua. Res. 34 (12), 10371045.

Pernet, F, Tremblay, R., Gionet, C., Landry, T., 2006. Lipid remodeling in wild and selectively bred hard clams at low temperatures in relation to genetic and physiological parameters. J. Exp. Biol. 209, 4663 - 4675.

Richard, N., 2006. Effet du taux et de la nature des lipides alimentaires sur les mécanismes intervenant dans la constitution des dépôts lipidiques (transport, captage, synthèse) chez la truie arc-en-ciel et le bar. Ecole doctorale des sciences du vivant, géosciences, sciences de l'environnement. Thèse de Doctorat à l'Université de Bordeaux I. 189 pp.

Rico-Villa, B., Le Coz, J.R., Mingant, C., Robert, R., 2006. Influence of phytoplankton diet mixtures on microalgae consumption, larval development and settlement of the Pacific oyster Crassostrea gigas (Thunberg). Aquaculture 256, 377-388.

Rico-Villa, B., Woerther, P., Mingant, C., Lepiver, D., Pouvreau, S., Hamon, M., Robert, R., 2008. A flow-through rearing system for ecophysiological studies of Pacific oyster Crassostrea gigas larvae. Aquaculture 282, 54-60.

Rico-Villa, B., Pouvreau, S., Robert, R., 2009. Influence of food density and temperature on ingestion, growth and settlement of Pacific oyster larvae, Crassostrea gigas, Aquaculture 287, 395-401.

Robert, R., Gérard, A., 1999. Bivalve hatchery technology: the current situation for the pacific oyster Crassostrea gigas and the scallop Pecten maximus in France. Aquat. Living Resour. $12,121-130$. 
Figures
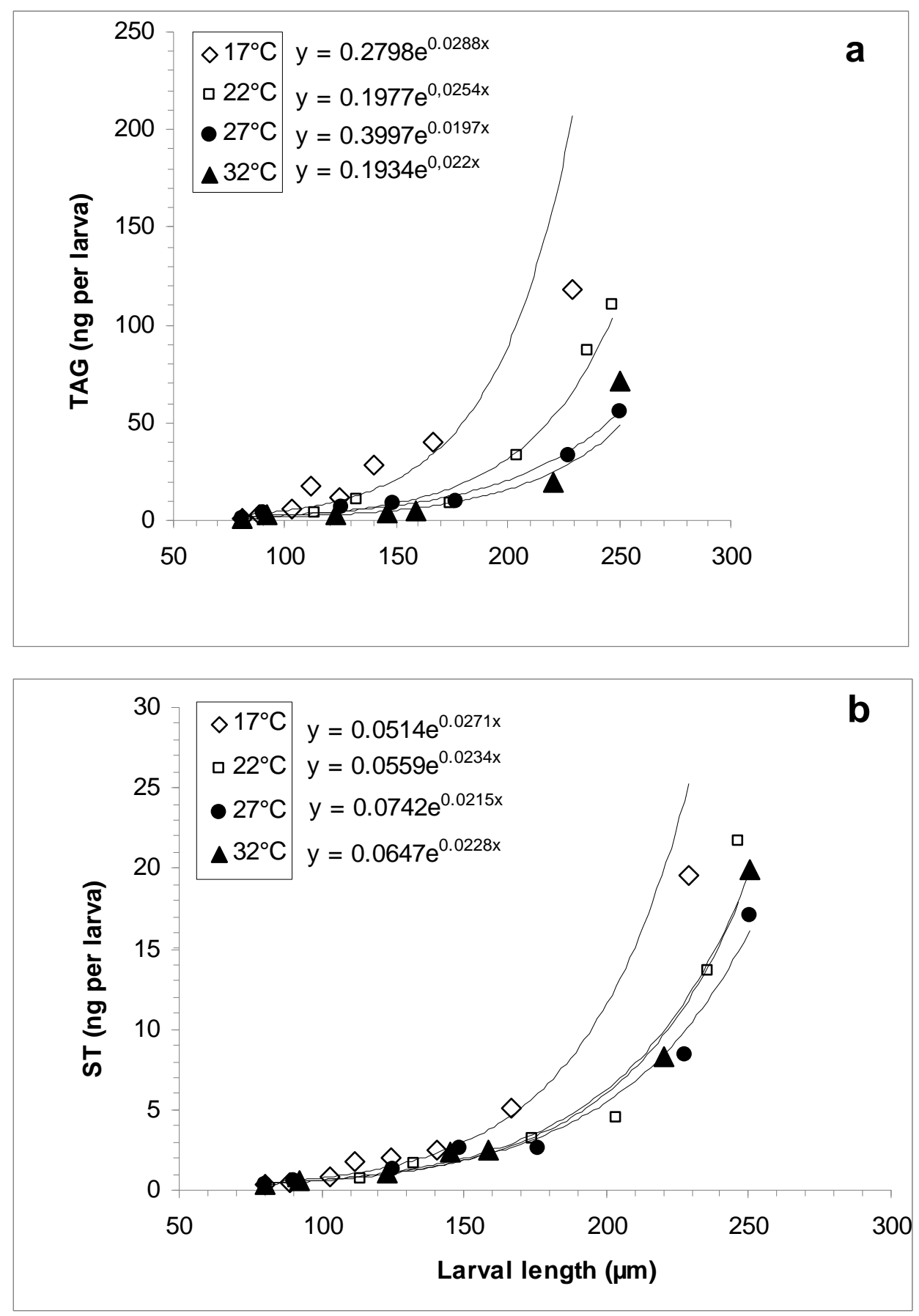

Fig. 1. Kinetics of triacylglycerol TAG (a) and sterol ST (b) accumulation, and their relationships with $C$. gigas larval size at four rearing temperatures from 17 to $32^{\circ} \mathrm{C}$. 


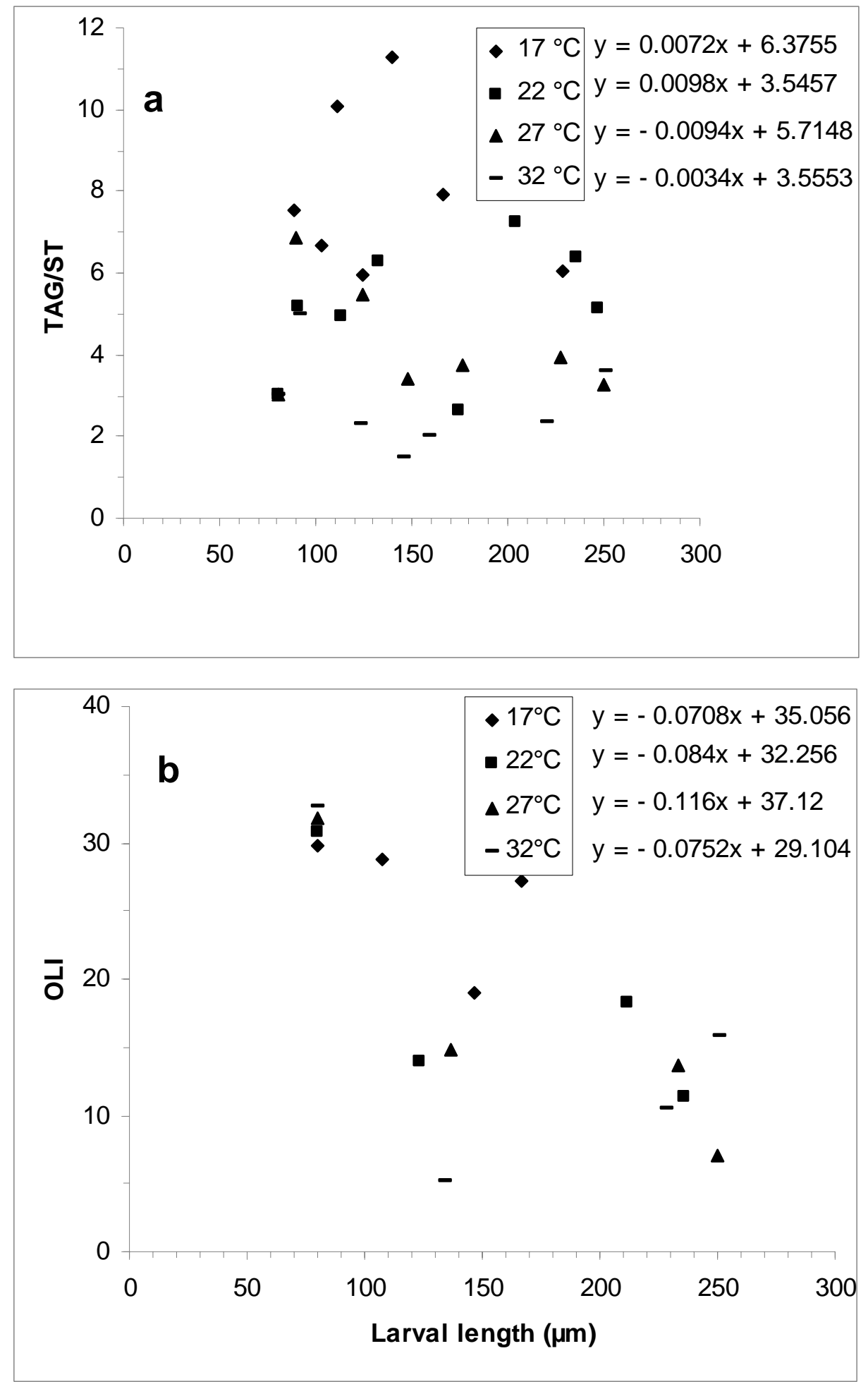

Fig. 2. Relationship of structural biochemical index TAG/ST (a) and overall lipid index OLI (b) with larval size in C. gigas reared at different temperatures from 17 to $32{ }^{\circ} \mathrm{C}$. 
Table 1.

Larval development performances (mean \pm standard deviation) of $C$. gigas reared at different temperatures. The values with the same letter in the same column are not significantly different at the $5 \%$ level. For each temperature Settlement was estimated 5 days following larval competence evaluation (end of larval rearing).

\begin{tabular}{|c|c|c|c|c|c|c|}
\hline $\begin{array}{l}\text { Temperature } \\
\left({ }^{\circ} \mathrm{C}\right)\end{array}$ & $\begin{array}{l}\text { Larval } \\
\text { life } \\
\text { duratio } \\
\mathrm{n} \\
\text { (days) }\end{array}$ & $\begin{array}{l}\text { Survival until } \\
\text { competence } \\
\text { excluding } \\
\text { embryogenesis } \\
(\%)\end{array}$ & $\begin{array}{l}\text { Mean larval } \\
\text { length (sd) at } \\
\text { the end of } \\
\text { larval rearing }\end{array}$ & $\begin{array}{l}\text { Larval growth } \\
\text { rates } \\
\left(\mu \mathrm{m} \text { day }^{-1}\right)\end{array}$ & $\begin{array}{l}\text { Larval } \\
\text { competen } \\
\text { ce }(\%)\end{array}$ & $\begin{array}{l}\text { Settlement } \\
(\%)\end{array}$ \\
\hline 17 & 23 & $92.0(6.6)^{a}$ & $229.1(38.5)^{a}$ & $7.1(1.8)^{a}$ & $17(3)^{a}$ & $12(7)^{a}$ \\
\hline 22 & 21 & $91.0(5.4)^{a}$ & $\underset{a b}{246.6}(33.4)$ & $8.7(1.8)^{a}$ & $37(10)^{b c}$ & $25(3)^{b}$ \\
\hline 27 & 18 & $93.6(2.7)^{\mathrm{a}}$ & $250.1(27.3)^{b}$ & $10.6(1.7)^{b}$ & $33(4)^{b}$ & $58(1)^{c}$ \\
\hline 32 & 18 & $92.4(2.9)^{\mathrm{a}}$ & $250.6(29.4)^{b}$ & $10.5(1.9)^{b}$ & $43(6)^{c}$ & $91(1)^{d}$ \\
\hline
\end{tabular}

